Ms. 4383

\title{
NITROGEN MINERALIZATION IN ACID SULFATE SOILS
}

\author{
by K. L. SAHRAWAT * \\ The International Rice Research Institute \\ Los Baños, Laguna, Philippines
}

Key words

Aerobic incubation Anaerobic incubation Low pH Nitrification Organic matter Release of ammonium Total N.

\section{Summary}

Mineralization of soil nitrogen studies with two acid sulfate soils under anaerobic and aerobic incubation at $30^{\circ} \mathrm{C}$ for 2 weeks showed that the mineral $\mathrm{N}$ was released and accumulated entirely as $\mathrm{NH}_{4}^{+}$in both soils. Nitrification did not occur in either of the soils under conditions that stimulate nitrification. The acid sulfate soils studied release good amounts of mineralizable $\mathrm{N}$, and, because of lack of nitrifying activity, denitrification may not be a serious problem in these soils.

\section{Introduction}

Agricultural productivity in millions of hectares of low-lying coastal land in the tropics is affected by the presence of potential and actual acid sulfate soils. Despite the high acidity and associated adverse effects on crop growth, these soils have characteristics favourable for wetland rice, for example, they are usually well supplied with plant nutrients from a high organic matter content and from $2: 1$ clay minerals ${ }^{7}$. Also flooding of these soils increases the $\mathrm{pH}$ to favourable values, where the iron concentration in solution falls below toxic levels and the availability of other nutrients is increased ${ }^{3,4,7}$. Perhaps this is the reason why some of the moderate acid sulfate soils are used for growing wetland rice.

Mineralization of organic matter in lowland rice soils is very important in that even in well-fertilized soils about two-third of the total $\mathrm{N}$ taken up by rice crop comes from the soil. Yet, information on mineralization of organic nitrogen in acid sulfate soils is lacking. These soils have an adequate supply of organic matter but are very acid, with a $\mathrm{pH}$, often below 4.0. So mineralization of $\mathrm{N}$ and nitrification may be affected. Sahrawat ${ }^{5}$ reported relatively low but adequate urease activity in two acid sulfate soils from the Philippines.

The objectives of this work were to study the mineralization of soil organic nitrogen

\footnotetext{
* Present address: International Crops Research Institute for the Semi-Arid Tropics (ICRISAT), ICRISAT Patancheru P O, Andhra Pradesh 502 324, India.
} 
Table 1. Properties of soils

\begin{tabular}{|c|c|c|c|c|c|c|}
\hline \multirow[t]{2}{*}{ Soil type } & \multirow[t]{2}{*}{$\begin{array}{c}\mathrm{pH} \\
(1: 1)\end{array}$} & \multirow[t]{2}{*}{$\underset{\%}{\text { Organic C }}$} & \multirow[t]{2}{*}{$\begin{array}{c}\text { Total N } \\
\%\end{array}$} & $\mathrm{NH}_{4}^{+}$ & $\mathrm{NO}_{3}^{-}$ & \multirow[t]{2}{*}{$\begin{array}{c}\text { Urease } \\
\text { activity * }\end{array}$} \\
\hline & & & & \multicolumn{2}{|c|}{ ppm } & \\
\hline Calalahan sandy loam & 3.4 & 1.57 & 0.110 & 58 & 0 & 8.8 \\
\hline Malinao loamy sand & 3.7 & 1.22 & 0.09 & 15 & 0 & 8.0 \\
\hline
\end{tabular}

* Urease activity expressed as $\mu \mathrm{g} \mathrm{NH}_{4}^{+}$released per g of soil per hour at $30^{\circ} \mathrm{C}$.

and its subsequent nitrification in two acid sulfate soils. Mineralizable $\mathrm{N}$ released under anaerobic incubation may serve as a useful index for soil nitrogen availability to wet land rice ${ }^{6}$.

The nitrification potential of a soil may give an idea about the extent of denitrification losses that could occur.

\section{Materials and methods}

The two acid sulfate soils used were surface $(0-15 \mathrm{~cm})$ samples collected from Calalahan and Malinao, Philippines. The soil samples were air-dried and ground to pass a 2-mm screen. Some properties of these soils are given in Table 1 . Soil $\mathrm{pH}$ was measured in the $1: 1$ soil to water suspension by a glass electrode. Organic $\mathrm{C}$ and total $\mathrm{N}$ were determined as described by Walkley and Black ${ }^{8}$ and Bremner ${ }^{1}$ respectively. $\mathrm{NH}_{4}^{+}$and $\mathrm{NO}_{3}^{-}$were measured after extraction with $2 \mathrm{M}$ $\mathrm{KCl}$ and by distillation of the filtered extracts with $\mathrm{MgO}$ and Devarda's alloy ${ }^{2}$. The urease activity of the soil was determined by a non-buffer method as described by Sahrawat. ${ }^{5}$.

\section{Incubation methods}

Anaerobic incubation at $30^{\circ} \mathrm{C}$ for 2 weeks. Ten g soil samples were transferred to $125 \mathrm{ml}$ conical flasks containing $20 \mathrm{ml}$ of distilled water. The flasks were covered with aluminium foil and incubated at $30^{\circ} \mathrm{C}$ for 2 weeks in an anaerobic incubator. After incubation, the amounts of $\mathrm{NH}_{4}^{+}$and $\mathrm{NO}_{3}^{-}$formed were estimated by analysis of the $2 \mathrm{M} \mathrm{KCl}$ extract ${ }^{2}$. The amounts of net $\mathrm{NH}_{4}^{+}-\mathrm{N}$ released during 2 weeks were determined by subtracting the amounts of the mineral $\mathrm{N}$ present in the soil before incubation.

Aerobic incubation. Ten g soil samples were incubated in $125 \mathrm{ml}$ conical flask at $50 \%$ WHC moisture and at $30^{\circ} \mathrm{C}$ for 2 weeks. The soil samples were aerated regularly by removing the aluminum foil from the mouth of the flask $\mathrm{NH}_{4}^{+}$and $\mathrm{NO}_{3}^{-}$produced during 2 weeks of incubation were determined by subtracting the amounts present in the soil before incubation.

\section{Results and discussion}

Mineralized nitrogen in the two acid sulfate soils accumulated entirely as $\mathrm{NH}_{4}^{+}$under both anaerobic and aerobic incubations at $30^{\circ} \mathrm{C}$ for 2 weeks. No nitrate would be detected even after 2 weeks of aerobic incubation. (Tables 2 and 3 ).

The net amounts of $\mathrm{NH}_{4}^{+}$released by the Calalahan and Malinao soils during anaerobic incubation were respectively 83 and $72 \mathrm{ppm}$ and the mineralizable $\mathrm{N}$ formed 
Table 2. Mineralizable nitrogen produced under anaerobic incubation at $30^{\circ} \mathrm{C}$ for 2 weeks

\begin{tabular}{lcc}
\hline \multicolumn{1}{c}{ Soil } & $\begin{array}{c}\mathrm{NH}_{4}^{+} \text {released } \\
(\mu \mathrm{g} / \mathrm{g} \text { soil })\end{array}$ & $\begin{array}{c}\text { Mineralizable } \mathrm{N} \text { as } \\
\% \text { of total } \mathrm{N}\end{array}$ \\
\hline Calalahan sandy loam & 83 & 7.5 \\
Malinao loamy sand & 72 & 8.0 \\
\hline
\end{tabular}

Table 3. Mineralizable nitrogen in the soils under aerobic $(50 \% \mathrm{WHC}$ moisture $)$ incubation at $30^{\circ} \mathrm{C}$ for 2 weeks

\begin{tabular}{lcc}
\hline \multicolumn{1}{c}{ Soil } & $\begin{array}{c}\text { Inorganic } \\
\mathrm{NH}_{4}^{+}\end{array}$ & $\begin{array}{c}\mathrm{N}(\mu \mathrm{g} / \mathrm{g} \text { soil }) \\
\mathrm{NO}_{3}^{-}\end{array}$ \\
\hline Calalahan sandy loam & 72 & 0 \\
Malinao loamy sand & 68 & 0 \\
\hline
\end{tabular}

7.5 and $8.0 \%$ of the total $\mathrm{N}$ content of these soils. Lack of nitrate formation in these soils may be due to lack of nitrifiers at the low pH of 3.4 and 3.7. However, these soils demonstrate adequate urease activity to hydrolyse urea ${ }^{5}$.

As noted earlier most acid sulfate soils have adequate organic matter and consequently release moderate amounts of $\mathrm{NH}_{4}^{+}$that could be helpful in nitrogen nutrition of plants if other growth adverse factors like iron toxicity, acidity etc. are absent. In fact in earlier studies it was observed that after $\mathrm{Fe}^{2+}$ in soil solution has fallen below toxic levels, the $\mathrm{N}$ supplying capacity of Calalahan acid sulfate was adequate to give good growth of rice without added $\mathrm{N}$ fertilizer ${ }^{6}$. Lack of nitrate formation in these soils should be viewed as a plus point for nitrogen nutrition as this will minimize losses through denitrification and leaching.

\section{Acknowledgement}

This work was carried out by the author at the international Rice Research Institute, los Banos, Laguna, Philippines under a post-doctoral research fellowship. I am greateful to Dr. F. N. Ponnamperuma, Principal Soil Chemist, IRRI, for his helpful advice and encouragement.

Received 1 April 1980

\section{References}

1 Bremner, J. M. 1965 In Agronomy 9, Methods of Soil Analysis. Ed. C. A. Black. pp 1149-1178. Am. Soc. Agron. Madison, Wisconsin.

2 Bremner, J. M. 1965 In Agronomy 9, Methods of Soil Analysis. Ed. C. A. Black. pp 1179-1237. Am. Soc. Agron. Madison, Wisconsin. 
3 Nhung, M. T. M. and Ponnamperuma F. N. 1966 Soil Sci. 102, 29-41.

4 Sahrawat, K. L. 1979 Plant and Soil 51, 143-144.

5 Sahrawat, K. L. 1980 Soil Biol. Biochem. 12, 195-196.

6 Sahrawat, K. L. 1980 Plant and Soil. 55, 181-187.

7 Van Breemen, N. and Pons, L. J. 1978 In International Rice Research Institute. Soils and Rice. Los Banos, Philippines.

8 Walkley, A. and Black, I. A. 1934 Soil Sci. 37, 29-38. 